\section{'Avalon', a New Pecan Cultivar with High Levels of Resistance to Pecan Scab}

\author{
Patrick J. Conner ${ }^{1}$ \\ University of Georgia, Tifton Campus, 2360 Rainwater Road, Tifton, GA \\ 31793
}

Additional index words. Carya illinoinensis, cultivar, breeding, genetics

\begin{abstract}
'Avalon' is a new pecan [Carya illinoinensis (Wangenh.) K. Koch] cultivar that was released by the University of Georgia (UGA) College of Agriculture and Environmental Sciences. 'Avalon' produces high yields of large nuts with good quality that mature in early October in south Georgia. Compared with most other cultivars with similar nut size and quality, 'Avalon' has superior resistance to pecan scab [Venturia effusa (G. Winter) Rossman \& W. C. Allen (basyonym Fuscladium effusum)]. High levels of resistance to this devastating disease make 'Avalon' especially suitable to planting in the southeastern U.S. where frequent summer rainfall provides a favorable environment for disease epidemics.
\end{abstract}

\section{Origin}

'Avalon' originated in Tifton, GA, from the cross 'Gloria Grande' $\times$ 'Barton' made in 2000. 'Gloria Grande' is a seedling selection discovered in Elloree, SC, that was introduced in 1923 (Sparks, 1992). 'Gloria Grande' produces large nuts with a thick shell and moderate percent kernel, and the tree has a high degree of resistance to pecan scab (Worley and Mullinix, 1997). 'Barton' is a selection from a cross between 'Moore' and 'Success' that was released by the U.S. Department of Agriculture in 1953 (Sparks, 1992). 'Barton' generally produces thinshelled nuts with poor kernel development and has good resistance to pecan scab (Worley and Mullinix, 1997). 'Avalon' was tested as Ga. 00-7-75 and first fruited in 2007 when it was observed to have large nuts, healthy foliage, and an absence of pecan scab infection. Foliar and stem scab lesions can result in premature defoliation and stem death. Lesions on nut shucks can reduce yield and nut quality, and in severe infections result in crop failure (Sparks, 1996). 'Avalon' was propagated for yield trials in 2009.

\section{Methods}

The testing location was Tifton, GA, on an experimental farm (lat. $31^{\circ} 30^{\prime} 34.74^{\prime \prime} \mathrm{N}$, long. $83^{\circ} 38^{\prime} 25.91^{\prime \prime} \mathrm{W}$ ). 'Avalon' was topworked into an existing yield trial of other

Received for publication 27 Aug. 2018. Accepted for publication 3 Oct. 2018.

${ }^{1}$ Corresponding author. E-mail: pconner@uga.edu. cultivars that were planted at this location in 2005. Topworked trees consisted of three 'Watson' and three 'Headquarters' trees grafted onto 'Elliott' seedling rootstocks. Trees for the yield trial were planted into a single orchard block with a tree spacing of $12.2 \mathrm{~m} \times 12.2 \mathrm{~m}$ (67 trees/ha) and at a completely randomized cultivar location. Nitrogen was applied annually at $112 \mathrm{~kg} \cdot \mathrm{ha}^{-1}$, whereas other nutrients and lime were applied according to leaf or soil analysis. Microsprinkler irrigation was used with one 75.7 L/h microsprinkler per tree. Fungicides and insecticides were applied following Georgia Extension Service recommendations (Hudson et al., 2006).

In 2009, 'Avalon' trees were topworked the original trees and placing bark grafts onto four or five major branches. Because 'Avalon' trees were topworked into this orchard, it was not possible to compare 'Avalon' tree yield directly with that of the other cultivars based on year from planting. However, yields from topworked 'Avalon' trees were similar to those of 7-year-old nontopworked trees in 2012 (Table 1) and 'Avalon' yields were into this trial by cutting off the branches of compared with nontopworked trees from that

A random 50-nut sample was taken from each tree annually to determine nut quality. Nuts were shelled and percentage edible kernel was calculated by weight. Nuts were harvested when $\approx 90 \%$ could be shaken from the tree with a mechanical shaker. Trees were monitored in the spring for budbreak phenology by monitoring twice weekly for the presence of extended individual leaflets in the exterior lower canopy, the presence of which were used to indicate budbreak. Dichogamy type and flowering period were determined by monitoring trees twice weekly in April and May. Pollen shed period was evaluated by tapping catkins and looking for the presence of shedding pollen. Stigma receptivity beginning was indicated by swollen stigmatic papillae and the presence of secretions on the stigmatic surface (Wetzstein and Sparks, 1989), giving the stigma a waxy look. The end of receptivity was determined by the presence of dry, brown-colored stigmas. Beginning in mid-September, trees were monitored twice weekly for shuck split by recording the percentage of 20 nuts observed around the tree canopy with dehisced shuck sutures. Leaf scab, nut scab, and black pecan aphid (Melanocallis caryaefoliae Davis) damage were evaluated in September of each year. Leaf scab was evaluated on a scale of 1 to 4 with the worst disease expression recorded, where $1=$ no scab lesions, $2=$ a few isolated lesions with restricted growth, $3=$ multiple lesions with expanding growth, and $4=$ stem scab lesions or defoliation. Nut scab was evaluated on a 1 to 5 scale with the average and worst disease expressions recorded, where $1=$ no scab lesions, $2=$ a few lesions with restricted growth, $3=$ multiple point forward.

Table 1. Average annual in-shell nut yield (kg per tree) of pecan cultivars at Tifton, GA, in the 7th through 12th year of growth (2012-17).

\begin{tabular}{lcccccccc}
\hline & \multicolumn{7}{c}{ Yr } \\
\cline { 2 - 8 } Cultivar & Trees (no.) & 7 & 8 & 9 & 10 & 11 & 12 & Avg \\
\hline Avalon $^{z}$ & 6 & 8 & $12 \mathrm{~b}^{\mathrm{y}}$ & 24 & $30 \mathrm{~b}$ & 38 & 46 & $22 \mathrm{ab}$ \\
Byrd & 5 & 19 & $21 \mathrm{a}$ & 23 & $43 \mathrm{a}$ & 27 & 24 & $26 \mathrm{a}$ \\
Desirable & 4 & 7 & $13 \mathrm{ab}$ & 13 & $17 \mathrm{c}$ & 23 & 23 & $16 \mathrm{c}$ \\
Pawnee & 3 & 7 & $9 \mathrm{~b}$ & 17 & $5 \mathrm{c}$ & 38 & 32 & $18 \mathrm{bc}$ \\
Gafford & 4 & 8 & $18 \mathrm{ab}$ & 14 & $28 \mathrm{~b}$ & 30 & 32 & $21 \mathrm{abc}$ \\
Significance & & NS & 0.036 & NS & 0.001 & NS & NS & 0.009 \\
\hline
\end{tabular}

${ }^{\mathrm{z}}$ Avalon was topworked into the orchard in 2009, and in 2012 when yields were similar to year 7 yields of nontopworked trees, they were considered to be 7 years old.

${ }^{\mathrm{y}}$ Mean separation within a column by Duncan's multiple range test, $P \leq 0.05$.

Table 2. Phenology and nut and kernel quality attributes of pecan cultivars at Tifton, GA, in the 7 th through 12th year of growth (2012-17).

\begin{tabular}{lccccrc}
\hline Cultivar & Trees (no.) & $\begin{array}{c}\text { Nuts per } \\
\text { cluster (no.) }\end{array}$ & Nut wt (g) & Kernel (\%) & $\begin{array}{r}\text { Avg day of } \\
\text { bud burst }^{z}\end{array}$ & $\begin{array}{c}\text { Avg day of } \\
50 \% \text { shuck split }\end{array}$ \\
\hline Avalon & 6 & $2.5 \mathrm{~b}^{\mathrm{x}}$ & $9.7 \mathrm{~b}$ & $53.5 \mathrm{~b}$ & 5 Apr. a & 3 Oct. b \\
Byrd & 5 & $3.3 \mathrm{a}$ & $9.3 \mathrm{c}$ & $58.0 \mathrm{a}$ & $25 \mathrm{Mar}$ c & 18 Sept. c \\
Desirable & 4 & $2.5 \mathrm{~b}$ & $10.2 \mathrm{a}$ & $48.9 \mathrm{c}$ & 1 Apr. b & 11 Oct. a \\
Pawnee & 3 & $3.3 \mathrm{a}$ & $9.7 \mathrm{~b}$ & $57.2 \mathrm{a}$ & 1 Apr. b & 9 Sept. d \\
Gafford & 4 & $2.6 \mathrm{~b}$ & $9.1 \mathrm{c}$ & $50.1 \mathrm{c}$ & 5 Apr. a & 12 Oct. a \\
Significance & & $<0.001$ & $<0.001$ & $<0.001$ & $<0.001$ & $<0.001$ \\
\hline
\end{tabular}

${ }^{\mathrm{Z}} \mathrm{Bud}$ burst is defined as the stage of growth when individual leaflets separate from the expanding bud.

${ }^{\mathrm{y}}$ Avalon was topworked into the orchard in 2009 , and in 2012 when yields were similar to year 7 yields of nontopworked trees, they were considered to be 7 years old.

${ }^{\mathrm{x}}$ Mean separation within a column by Duncan's multiple range test, $P \leq 0.05$. 
lesions with $0 \%$ to $10 \%$ coverage, $4=11 \%$ to $50 \%$ coverage, and $5=51 \%$ to $100 \%$ coverage or nut drop. Black pecan aphid damage was rated on a four-point scale observing the lower interior canopy: $1=$ no damage; $2=$ light chlorotic spotting, $0 \%$ to $25 \%$ leaves affected; $3=$ moderate chlorotic spotting, $26 \%$ to $75 \%$ leaves affected; and $4=$ heavy chlorotic spotting, $76 \%$ to $100 \%$ leaves affected.

In addition to the yield trial, a minimally sprayed scab resistance trial of multiple cultivars is maintained at a nearby site on the same farm. This orchard gets similar care to the yield trial, except that only two sprays are applied in August to control hickory shuckworm (Cydia caryana Fitch) and pecan scab is left untreated. One to three trees of various cultivars and selections are grafted into this trial to observe scab infection levels on untreated trees in a high disease pressure situation using the methods described earlier. Nut yield and quality data are not obtained from this orchard.

Yield data for each year of growth were calculated for each clone by averaging all the replication trees for that clone for the given year. Quality and pest resistance characteristics in the yield trial were calculated by averaging years 7-12. Differences between cultivars were determined using one-way analysis of variance with mean separation by Duncan's multiple range test $(P<0.05)$. Pest resistance ratings in the scab resistance trial were evaluated in 2013-17 and years were treated as reps for each cultivar. Statistical analysis was performed using SigmaPlot 12.3 statistical software (Systat Software, San Jose, CA).

\section{Description and Performance}

Yields of 'Avalon' topworked trees averaged $8 \mathrm{~kg}$ in 2012. This yield was similar to that of three of the four nontopworked cultivars in the yield trial that were in their seventh year of growth that year (Table 1). From that point forward, 'Avalon' yields continued to increase each year. This is in contrast to 'Byrd', 'Pawnee', and 'Gafford', which all had years in which yields were lower than the previous year, a common feature of an irregularly bearing crop like pecan (Wood et al., 2003). The average yield of 'Avalon' was similar to that of 'Byrd', 'Pawnee', and 'Gafford', and greater than that of 'Desirable'. 'Avalon' produced 2.5 nuts per cluster, which is equal to the number of nuts per cluster produced by 'Desirable' (Table 2). A paramount attribute of 'Desirable' is the ability of the cultivar to thin the number of nuts per cluster to two to three nuts, reducing the need for crop load thinning treatments and increasing regular bearing (Sparks, 1997). Because 'Avalon' has a similar number of nuts per cluster as 'Desirable' and yields increased in each year of this test, 'Avalon' appears to be a cultivar with a reduced need

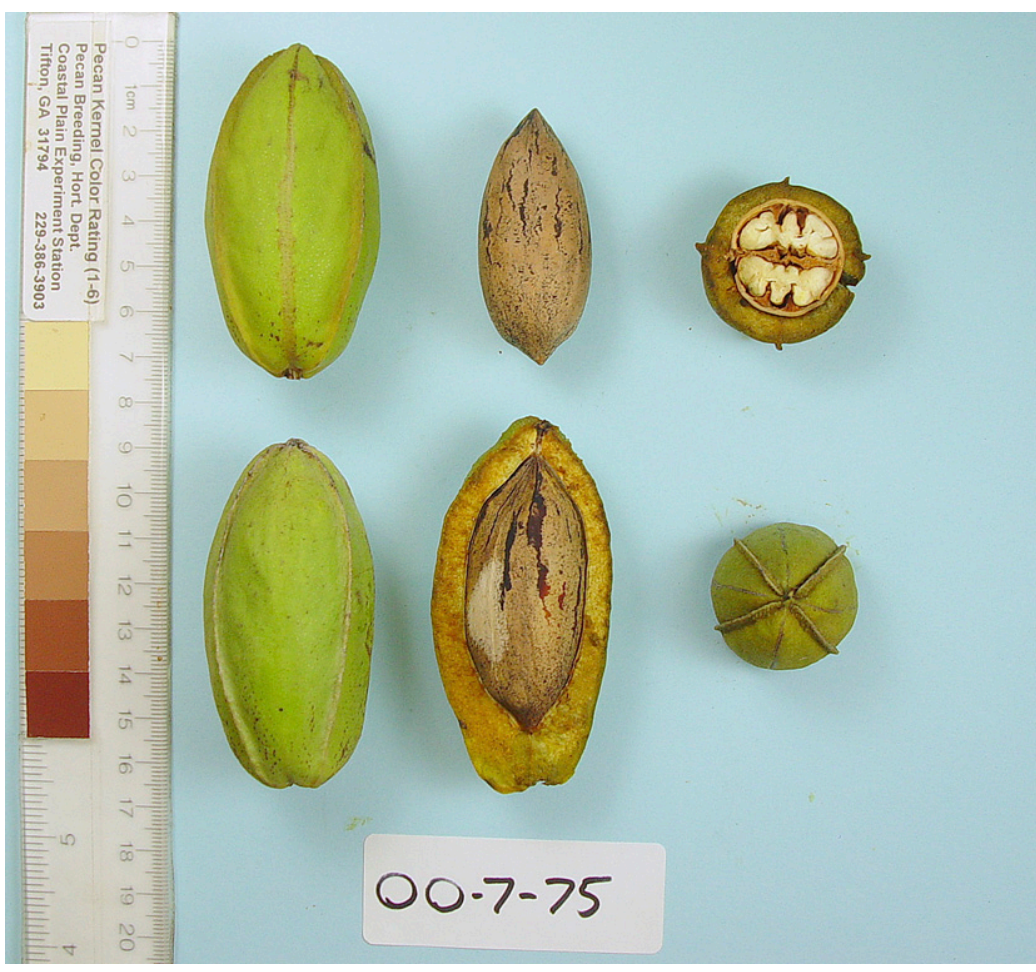

Fig. 1. 'Avalon' nut and shuck attributes.

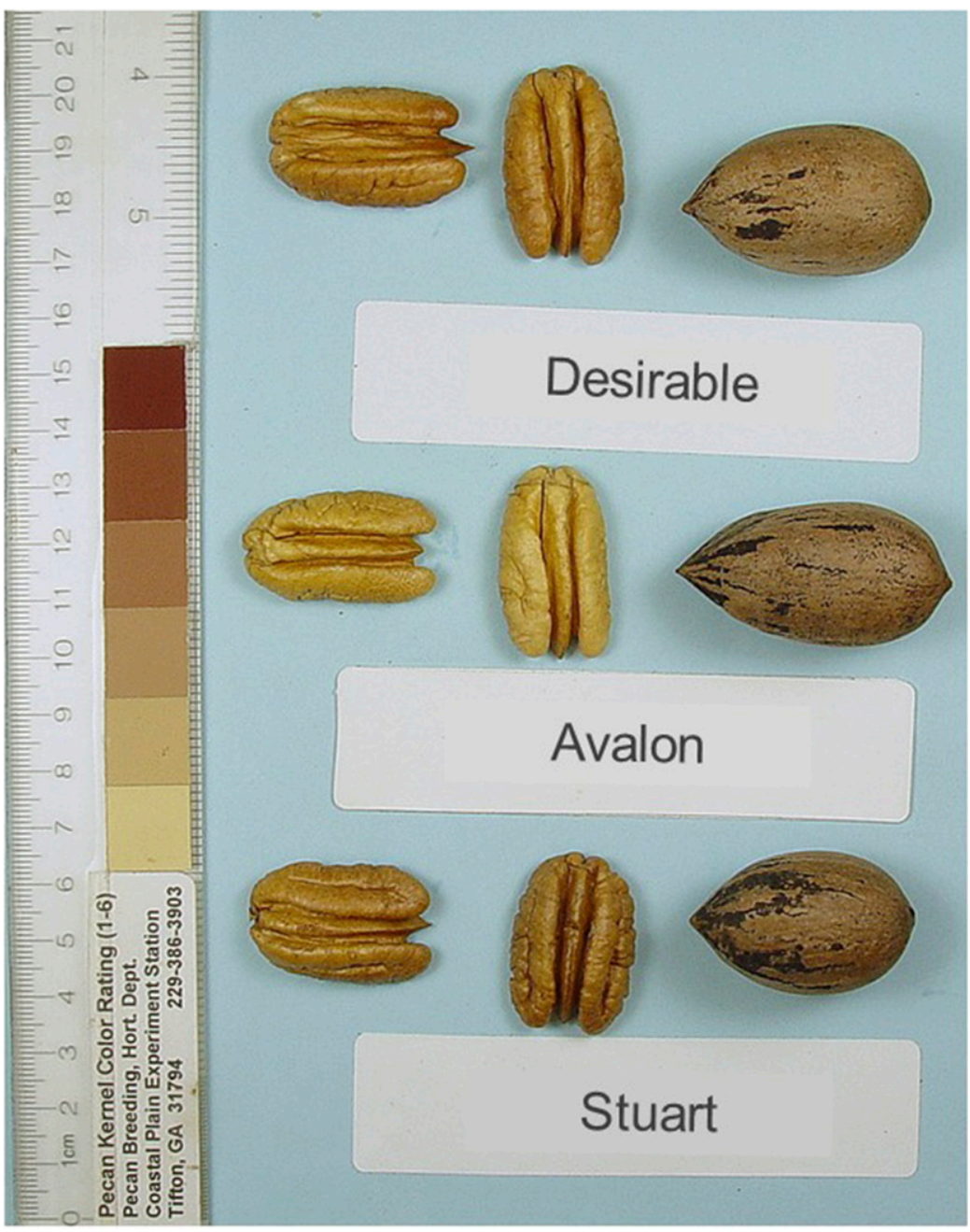

Fig. 2. 'Avalon' nut and kernel attributes in comparison with 'Desirable' and 'Stuart'. 


\begin{tabular}{|c|c|c|c|c|c|c|c|c|c|c|c|c|c|c|c|c|c|c|c|c|c|}
\hline Cultivar & Type $^{z}$ & \multicolumn{20}{|c|}{ Day of the year } \\
\hline & & $\begin{array}{l}1 \\
1 \\
1\end{array}$ & \begin{tabular}{l|l|l}
1 & 1 \\
1 & 1 \\
2 & 3
\end{tabular} & \begin{tabular}{l|l|l}
1 & 1 \\
1 & 1 \\
3 & 1
\end{tabular} & $\begin{array}{ll}1 & 1 \\
4 & 1 \\
\end{array}$ & $\begin{array}{l}1 \\
1 \\
6\end{array}$ & $\begin{array}{l}1 \\
1 \\
7\end{array}$ & $\begin{array}{l}1 \\
1 \\
8\end{array}$ & \begin{tabular}{l|l|l}
1 & 1 \\
1 & 2 \\
9 & 2
\end{tabular} & $\begin{array}{l}1 \\
2 \\
1\end{array}$ & $\begin{array}{l}1 \\
2 \\
2\end{array}$ & $\begin{array}{l}1 \\
2 \\
3\end{array}$ & $\begin{array}{l}1 \\
2 \\
4\end{array}$ & $\begin{array}{l}1 \\
2\end{array}$ & $y^{3}$ & & & & & & \begin{tabular}{l|l}
1 & 1 \\
3 & 3 \\
3 & 4
\end{tabular} \\
\hline Avalon & II & & & & & & & & & & & & & & & & & & & & \\
\hline & & & & & & & & & & & & & & & & & & & & & \\
\hline Amling & I & & & & & & & & & & & & & & & & & & & & \\
\hline & & & & & & & & & & & & & & & & & & & 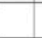 & & \\
\hline & & & & & & & & & & & & & & & & & & & & & \\
\hline Byrd & I & & & & & & & & & & & & & & & & & & & & \\
\hline & & & & & & & & & & & & & & & & & & & & & \\
\hline & & & & & & & & & & & & & & & & & & & & & \\
\hline Desirable & I & & & & & & & & & & & & & & & & & 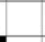 & & & \\
\hline & & & & & & & & & & & & & & & & & & & & & \\
\hline Gafford & I & & & & & & & & & & & & & & & & & & 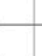 & & \\
\hline & & & & & & & & & & & & & & & & & & & & & \\
\hline & & & & & & & & & & & & & & & & & & & & & \\
\hline Mandan & I & & & & & & & & & & & & & & & & & & & & \\
\hline & & & & & & & & & & & & & & & & & & & & & \\
\hline & & & & & & & & & & & & & & & & & & & & & \\
\hline Pawnee & I & & & & & & & & & & & 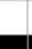 & & & & & & & & & \\
\hline Pollen Shed & & & & & & & & & & & & & & & & & & & & & \\
\hline Pistil & & & & & & & & & & & & & & & & & & & & & \\
\hline Kecep & & & & & & & & & & & & & & & & & & & & & \\
\hline
\end{tabular}

Fig. 3. Average pollen shed and pistil receptivity for 'Avalon' and common protandrous pecan cultivars in Tifton, GA. for crop load thinning to maintain regular bearing.

'Avalon' produced a large nut of good quality (Table 2; Fig. 1). Nut shape is oblong with a round cross section and an acuminate base and tip (Fig. 1). Striping is common on the apex end of the nut, and spotting is common over the entire nut. Although generally free from packing tissue, the dorsal groove on the kernel is not as wide as that in 'Desirable' (Fig. 2). The basal cleft of the kernel is deep and can retain packing tissue. The nut shells well and easily produces intact kernel halves.

The nut weight of 'Avalon' was $9.7 \mathrm{~g}$, which is similar to that of 'Pawnee' and greater than that of 'Gafford' and 'Byrd', but less than that of 'Desirable' (Table 2). Avalon nuts averaged 54\% kernel, greater than 'Desirable' and 'Gafford', and less than 'Pawnee' and 'Byrd'. Kernel color is cream to golden with no veining or spotting (Fig. 2).

Time of spring budbreak is later than that of 'Byrd', 'Desirable', and 'Pawnee' and similar to that of 'Gafford'. 'Avalon' budbreak is late enough to avoid most spring frosts in South Georgia. 'Avalon' is protogynous (type II), with early stigma receptivity and mid to late season pollen shed (Fig. 3) 'Avalon' will pollinate 'Amling', 'Desirable', 'Gafford', 'Mandan', and 'Pawnee', and will be pollinated by 'Amling', 'Byrd',

Table 3. Pest resistance of pecan cultivars in a sprayed orchard at Tifton, GA, in the 7th through 12th year of growth (2012-17).

\begin{tabular}{|c|c|c|c|c|c|}
\hline Cultivar & Trees (no.) & Leaf scab (1 to 4 scale $)^{z}$ & Avg. nut scab (1 to 5 scale $)^{y}$ & Max. nut scab (1 to 5 scale $)^{x}$ & Black pecan aphid damage (1 to 4 scale $)^{\mathrm{w}}$ \\
\hline Avalon $^{v}$ & 6 & $1.0 \mathrm{~b}^{\mathrm{u}}$ & $1.0 \mathrm{c}$ & $1.0 \mathrm{~d}$ & $2.0 \mathrm{a}$ \\
\hline Desirable & 4 & $2.8 \mathrm{a}$ & $3.4 \mathrm{a}$ & $4.5 \mathrm{a}$ & $1.5 \mathrm{~b}$ \\
\hline Pawnee & 3 & $1.2 \mathrm{~b}$ & $1.0 \mathrm{c}$ & $2.3 \mathrm{c}$ & $1.6 \mathrm{~b}$ \\
\hline Significance & & $<0.001$ & $<0.001$ & $<0.001$ & $<0.001$ \\
\hline
\end{tabular}

${ }^{\mathrm{z}_{1}} 1=$ no scab lesions, 2 = a few isolated lesions with restricted growth, $3=$ multiple lesions with expanding growth, $4=$ stem scab lesions or defoliation.

${ }^{\mathrm{y}} 1=$ no scab lesions, $2=\mathrm{a}$ few lesions with restricted growth, $3=$ multiple lesions, $0 \%$ to $10 \%$ coverage, $4=11 \%$ to $50 \%$ coverage, $5=51 \%$ to $100 \%$ coverage or nut drop. Average damage seen on nuts over the tree.

${ }^{\mathrm{x}} 1=$ no scab lesions, $2=\mathrm{a}$ few lesions with restricted growth, $3=$ multiple lesions, $0 \%$ to $10 \%$ coverage, $4=11 \%$ to $50 \%$ coverage, $5=51 \%$ to $100 \%$ coverage or nut drop. Maximum damage seen on any nut.

${ }^{\mathrm{w}} 1$ = no damage, 2 = light chlorotic spotting, $0 \%$ to $25 \%$ leaves affected, $3=$ moderate chlorotic spotting, $26 \%$ to $75 \%$ chlorotic spotting, $4=$ heavy chlorotic spotting, $76 \%$ to $100 \%$ leaves affected.

vAvalon was topworked into the orchard in 2009, and in 2012 when yields were similar to year 7 yields of nontopworked trees, they were considered to be 7 years old.

"Mean separation within a column by Duncan's multiple range test, $P \leq 0.05$.

Table 4. Pest resistance of pecan cultivars in a minimally sprayed orchard at Tifton, GA (2013-17).

\begin{tabular}{lccccc}
\hline Cultivar & Trees (no.) & Leaf scab (1 to 4 scale $)^{\mathrm{z}}$ & ${\text { Avg. nut scab }(1 \text { to 5 scale })^{\mathrm{y}}}$ & Max. nut scab (1 to 5 scale) $^{\mathrm{x}}$ & Black pecan aphid damage $\left(1\right.$ to 4 scale) $^{\mathrm{w}}$ \\
\hline Avalon & 3 & $1.0 \mathrm{~b}^{\mathrm{v}}$ & $1.0 \mathrm{~d}$ & $1.3 \mathrm{c}$ & $2.7 \mathrm{abc}$ \\
Desirable & 1 & $3.8 \mathrm{a}$ & $5.0 \mathrm{a}$ & $5.0 \mathrm{a}$ & $2.6 \mathrm{abc}$ \\
Elliott & 1 & $1.0 \mathrm{~b}$ & $1.0 \mathrm{~d}$ & $1.0 \mathrm{c}$ & $1.8 \mathrm{c}$ \\
McMillan & 1 & $1.0 \mathrm{~b}$ & $1.0 \mathrm{~d}$ & $1.4 \mathrm{c}$ & $2.0 \mathrm{c}$ \\
Pawnee & 1 & $2.0 \mathrm{~b}$ & $4.8 \mathrm{ab}$ & $4.8 \mathrm{a}$ & $2.4 \mathrm{bc}$ \\
Stuart & 1 & $2.2 \mathrm{~b}$ & $4.6 \mathrm{ab}$ & $5.0 \mathrm{a}$ & $3.6 \mathrm{a}$ \\
Sumner & 1 & $1.8 \mathrm{~b}$ & $2.2 \mathrm{c}$ & $3.4 \mathrm{~b}$ & $2.4 \mathrm{c}$ \\
Zinner & 2 & $1.9 \mathrm{~b}$ & $4.4 \mathrm{~b}$ & $4.9 \mathrm{a}$ & $3.1 \mathrm{ab}$ \\
Significance & & $<0.001$ & $<0.001$ & $<0.001$ & 0.013 \\
\hline
\end{tabular}

${ }^{\mathrm{z}} 1=$ no scab lesions, $2=\mathrm{a}$ few isolated lesions with restricted growth, $3=$ multiple lesions with expanding growth, $4=$ stem scab lesions or defoliation.

${ }^{y_{1}} 1=$ no scab lesions, $2=\mathrm{a}$ few lesions with restricted growth, $3=$ multiple lesions, $0 \%$ to $10 \%$ coverage, $4=11 \%$ to $50 \%$ coverage, $5=51 \%$ to $100 \%$ coverage or nut drop. Average damage seen on nuts over the tree.

${ }^{\mathrm{x}} 1=$ no scab lesions, 2 = a few lesions with restricted growth, $3=$ multiple lesions, $0 \%$ to $10 \%$ coverage, $4=11 \%$ to $50 \%$ coverage, $5=51 \%$ to $100 \%$ coverage or nut drop. Maximum damage seen on any nut.

${ }^{\mathrm{w}} 1$ = no damage, 2 = light chlorotic spotting, $0 \%$ to $25 \%$ leaves affected, $3=$ moderate chlorotic spotting, $26 \%$ to $75 \%$ chlorotic spotting, $4=$ heavy chlorotic spotting, $76 \%$ to $100 \%$ leaves affected.

"Mean separation within a column by Duncan's multiple range test, $P \leq 0.05$, with years treated as replications. 
'Desirable', 'Gafford', and 'Pawnee'. Time of $50 \%$ shuck split is $1-7$ Oct. at Tifton, which is $\approx 1$ week earlier than 'Desirable' (Table 2), giving 'Avalon' an early midseason harvest date.

'Avalon' is exceptionally resistant to pecan scab, with no infection having been observed in the sprayed yield trial (Table 3). In the minimally sprayed scab resistance trial at Tifton, 'Avalon' was generally free from scab infection with only trace amounts being seen on a few nut clusters (Table 4). In comparison, susceptible cultivars such as 'Desirable', 'Pawnee', and 'Byrd' had significant scab in sprayed trials and nearly complete crop loss in the minimally sprayed trials. 'Avalon' performed better than the moderately resistant 'Sumner' and similar to highly resistant cultivars such as 'Elliott' and 'McMillan' in the minimally sprayed trials. Damage from the black pecan aphid was higher than that from all other cultivars in the sprayed trials (Table 3) and among the highest in the minimally sprayed trial (Table 4). Both parents show relatively high susceptibility to black pecan aphid damage, and 'Avalon' should be monitored closely for this pest.

\section{Availability}

'Avalon' will be a patented cultivar (USPP applied for) and is owned by the University of Georgia Research Foundation. Propagation rights are controlled by the University of Georgia Research Foundation, Technology Commercialization Office, GSRC Boyd Building, Athens, GA 306027411 (www.ovpr.uga.edu/tco/). A list of nurseries licensed to propagate 'Avalon' pecan can be obtained by contacting the author.

\section{Literature Cited}

Hudson, W., J. Brock, S. Culpepper, and L. Wells. 2006. Georgia pecan pest management guide. Univ. of Georgia College of Agr. Bul. 841.

Sparks, D. 1992. Pecan cultivars: The orchards foundation. Pecan Production Innovations, Watkinsville, GA

Sparks, D. 1996. A climatic model for pecan production under humid conditions. J. Amer. Soc. Hort. Sci. 121:908-914.

Sparks, D. 1997. 'Desirable' pecan. Fruit Var. J. 51:2-7.

Wetzstein, H. and S. Sparks. 1989. Stigma-pollen interactions in pecan. J. Amer. Soc. Hort. Sci. 114:355-359.

Wood, B., P. Conner, and R. Worley. 2003. Relationship of alternate bearing intensity in pecan to fruit and canopy characteristics. HortScience 38:361-366.

Worley, R.E. and B.G. Mullinix. 1997. Pecan cultivar performance at the Coastal Plain Experiment Station, 1921-1994. Georgia Agr. Expt. Sta. Bul. 426, Athens, GA. 